\title{
PENGARUH ATMOSFER PUSAT BELANJA PADA SHOPPING VALUE
}

\author{
Astrid Kusumowidagdo \\ Institut Teknologi Bandung \\ e-mail: astrid_kusumo@yahoo.com \\ Agus Sachari \\ Institut Teknologi Bandung \\ Pribadi Widodo \\ Institut Teknologi Bandung
}

\begin{abstract}
At the moment, the creation of shopping environment design that provides certain sensation and experience become strategy of the shopping center. This research aims to find out about the influence of shopping center's atmosphere towards shopping value. The formative factors of shopping centre's atmosphere are architectural features, interior features and support facilities. The research begins with a focus group to adjust the indicators of the previous research to the present research's object. The next stage of research is done with a multiple regression analysis. The research object is the atmosphere condition of Senayan City shopping center in Jakarta and the subjects are samples totaling to sixty people. The samples are visitors from the middle-class segment between the age of 18-35. The research finds that architectural features, interior features and support facilities collectively bring an influence towards shopping value in Senayan City Pusat belanja, wether partially, only interior features show the significant influence towards shopping value.
\end{abstract}

Keywords: design, atmosphere, shopping centre, shopping value.

\begin{abstract}
Abstrak
Saat ini penciptaan lingkungan belanja dengan yang memberikan sensasi dan pengalaman telah menjadi bagian dari strategi bisnis pusat belanja. Penelitian ini bertujuan untuk menelusuri pengaruh atmosfer pusat belanja terhadap shopping value. Atmosfer pusat belanja dibentuk oleh faktor-faktor yaitu fitur arsitektur, fitur interior dan fasilitas penunjang. Penelitian ini diawali dengan focus group untuk penentuan indikator yang tepat dan dilanjutkan dengan survey pada 60 orang dengan usia 18-35 tahun yang bersegmen menengah. Obyek penelitian adalahatmosfer dari pusat belanja Senayan City. Hasil penelitian menunjukkan terdapat hubungan dari faktor-faktor atmosfer pusat belanja secara serempak pada shopping value, sedangkan secara parsial hanya fitur interior yang memberikan pengaruh signifikan pada shopping value.
\end{abstract}

Kata Kunci: desain, atmosfer, pusat belanja, shopping value.

\section{PENDAHULUAN}

Dalam perkembangan masa kini, pusat belanja dengan tipe bangunan bertingkat yang disertai dengan ruang-ruang sosial di dalamnya, atau yang sering disebut pusat belanja semakin marak dibangun. Selain jumlahnya yang mengalami peningkatan karena prospek properti Indoneisa jumlah kelas menengah (Kurniawan, 2012; Soeprajitno, 2012). yang meningkat beberapa tahun belakangan. Jika dicermati, tampilan fisik sebagai pembentuk lingkungan belanja tampak berbeda. (Kusumowidagdo et al., 2013a,b). Pada era-era awal pusat belanja era 1970, memiliki tipologi big box tanpa air conditioner dan dibagai dalam petak-petak berukuran kecil yang dihubungkan oleh koridor sempit. Pada era 1985, pusat belanja era memiliki koridor yang lebih lebar, dengan 
pengkondisian udara dan tata cahaya yang baik serta dilengkapi dengan atrium yang cukup tinggi dan luas untuk mewadahi aktifitas sosial. Selain itu dijumpai pula fasilitas foodcourt/pusat makanan yang didesain dengan baik untuk melengkapi aktifitas belanja. Pada era berikutnya, setelah krisis ekonomi yang berkepanjangan di tahun 1998, pada tahun 2005 bermunculan berbagai tipologi desain fisik lingkungan belanja yang berbeda, dari arsitekturnya tampak bentuk-bentuk lengkung yang luwes, pengelompokkan toko yang lebih terarah, pemilihan penyewa yang dipertimbangkan dengan baik, adanya tempat-tempat publik yang mendukung, serta berbagai fasilitas, termasuk pula di dalamnya terintegrasi konsep bisnis. Selain tampilan fisik, berbagai even sosial dan pencitraan lebih gencar dilakukan di era ini dengan bantuan teknologi. (Kusumowidagdo et al., 2013a,b).

Pusat belanja dalam ruang arsitektural pelingkupnya, tidak hanya merefleksikan dimensi-dimensi yang matematis, terhitung dan keterukuran standar kenyamanan, namun di dalamnya terkandung sebuah jiwa, spirit dan tempat dari aura yang membentuk suasana tertentu yang disebut dengan atmosfer. Kotler (1973) menggelindingkan isu atmospheric dalam memberikan ilustrasi mengenai gambaran lingkungan pembelian yang memberikan pengaruh dari pengkondisian sense manusia, aural, visual, olfactory dan dimensi taktil. Selain Kotler, pengaruh suasana lingkungansebagai pembentuk pengalaman berbelanja juga dikaji Relph (1973) dan Baker et al. (1992). Kata-kata atmosfer secara meluas juga dipergunakan pada bidang arsitektur, Zumthor (2006), juga mempergunakan kata-kata tersebut untuk memberikan gambaran pada suasana arsitektural yang memberikan aura pada lingkungan. Selanjutnya pada area riset perilaku konsumen, dimulai dari Mehrabian and Russel (1978), dilanjutkan dengan Donovan dan Rossiter (1982), hingga Turley and Miliman (2000) serta berbagai penelitian lain.

Pada perkembangan berikutnya, seiring dengan kemajuan jaman dan teknologi, terdapat perubahan era menuju era pengalaman (experience) yang memberikan sensasi melalui pengalaman berbagai pengamat (Pine and Gilmore, 1998; Burns and Neiser, 2006; Fiore and Kim,
2007). Bahkan bidang desainpun tidak terlepas dari prinsip ini (Williams, 2006). Penciptaan experience adalah rationale dari sebuah desain, yang pada konteks ini adalah desain lingkungan belanja. Lingkungan belanja akan memberikan pengalaman yang memberikan nilai tambah untuk suasana belanja. Suasana belanja yang mendukung telah terbukti berpengaruh dalam perilaku toko (Turley and Milliman, 2000), mendukung pemilihan toko, (Kusumowidagdo, 2005), keinginan bereksplorasi dalam toko (Donovan and Rossiter, 1982) serta mempengaruhi shopping value (Spena et al.,2012; Prahalad and Rawasramy, 2004; Caru and Cova, 2006; Sands, Oppewal and Beverland, 2010).

Didukung dengan beberapafakta di atas menunjukkan bahwa terdapatnya hubungan antara pengalaman yang dibentuk dengan perilaku belanja termasuk di dalamnya shopping value pada pusat belanja. Maka penelitian ini ingin menguak lebih jauh pengaruh lingkungan belanja dalam konteks ini atmosfer pusat belanja terhadap shopping value di Indonesia.

\section{KAJIAN PUSTAKA}

Sebuah pusat belanja memiliki beberapa faktor yang mempengaruhi kesuksesannya, antara lain lokasi, visibility, kemudahan akses dan pencapaian, luasan, desain dan perencanaan, anchor tenant, tenant mix, strategi pencitraan, manajemen dan marketing serta strategi berorientasi pelanggan (Wee and Tong, 2005).

Kesembilan aspek ini saling terintegrasi untuk mendukung sustainabilitas sebuah pusat belanja. Sehingga desain fisik dan perencanaannya menjadi bagian yang penting dalam tataran strategis sebagai pertimbangan bagi pihak manajemen. (Kusumowidagdo et al., $2012 \mathrm{a}$ ).

Dalam penelitian sebelumnya, Kusumowidagdo et al. (2012 a,b), telah menemukan pengaruh atmosfer pusat belanja berpengaruh pada persepsi fisik pusat belanja, dan umur pusat belanja mempengaruhi perilaku pengunjung. Kusumowidagdo et al. (2012a) mendefinisikan variabel-variabel pembentuk atmosfer dengan rujukan pada Kramer (2008) melalui proses focus group sebagai berikut, fitur arsitektur, fitur interior dan fasilitas penunjang. 


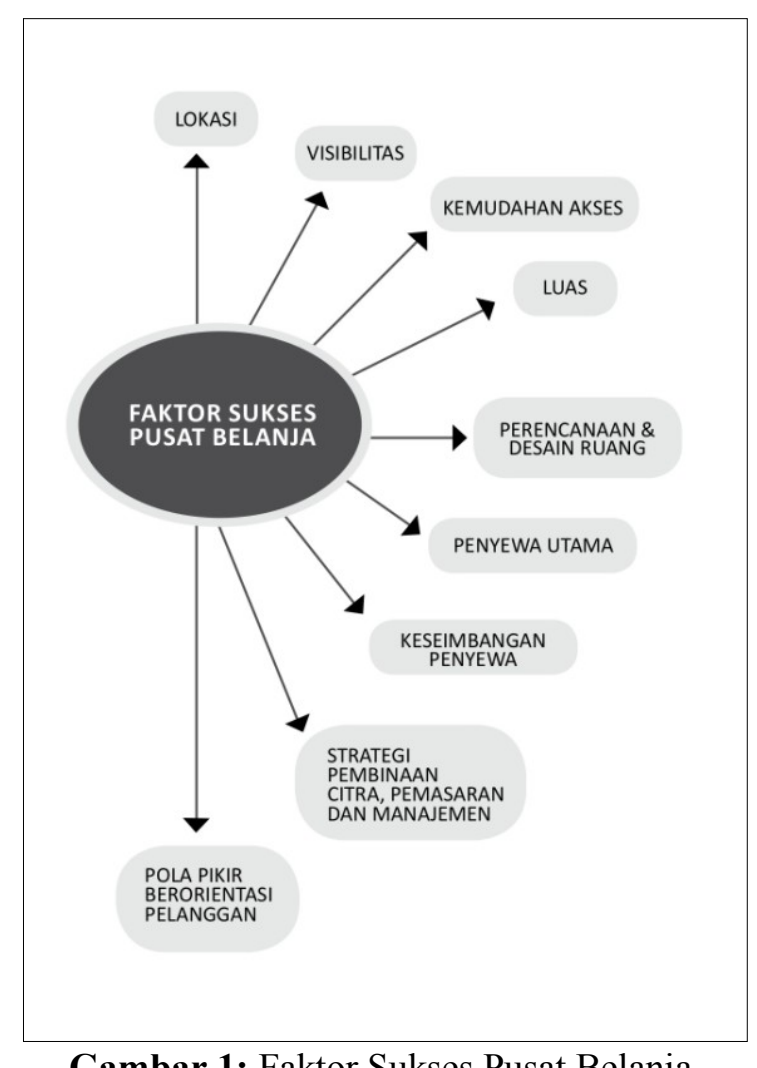

Sumber: (Wee and Tong, 2007 dalam Kusumowidagdo et al., 2012a)

Fitur arsitektur dapat didefinisikan sebagai elemen luar ruang sebagai pembangun ruang pelingkup pusat belanja yaitu elemen eksterior dan konfigurasi bangunan (Kramer, 2008, Kusumowidagdo et al., 2012 c,d). Elemen arsitektur terbukti telah memberikan pengaruh terhadap identifikasi tempat pada pusat belanja. (Kusumowidagdo et al., 2012 c,d) danmempengaruhi status relasi antara pengunjung dan lingkungan pusat belanja (Kusumowidagdo et al., 2012c,d). Selain identifikasi tempat, elemen arsitektur ini, Kramer (2008) menjabarkan kategori fitur arsitektur dalam berbagai elemennya yaitu material bangunan, entrance bangunan, kanopi, signage, pencahayaan dan konfigurasi bangunan sebagai faktor yang penting diperhatikan. Adapun tampilan arsitektur, paduan material (Barr and Broudy, 1997; Kramer, 2009; Kusumowidagdo, et. al. $2012 \mathrm{c}$ ), posisi entrance (Barr and Broudy, 1997; Wee and Tong, 2007; Kramer, 2008; Kusumowidagdo et al., 2012 c), lobby, dan penataan ruang luar (Wee and Tong, 2007; Kramer, 2008; Kusumowidagdo et al., 2012 c), terbukti memiliki pengaruh terhadap perilaku pengunjung dalam berbelanja.
Fitur interior pusat belanja dapat didefinisikan adalah ruang dalam dari arsitektur pusat belanja. Dalam Kramer (2008) yang termasuk ke dalam fitur interior yang penting untuk diperhatikan adalah pengelolaan ruang penyewa, fleksibilitas ruang, kios, jumlah lantai, tampilan depan toko, ukuran toko, basement, dinding interior, plumbing, pencahayaan, material pelapis lantai dan pengkondisian udara. Fitur interior yaitu penampilan toko (Gardner, 1985; Titus and Everett, 1995; Kusumowidagdo, 2005, Wee and Tong, 2007; Kramer, 2008;), windows display (Kramer, 2008, Kusumowidagdo, 2009), zoning (Kramer, 2008), pencahayaan dalam toko (Kusumowidagdo, 2010; Kusumowidagdo et al., 2012 c, d), pencahayaan di ruang publik (Kusumowidagdo et al., 2012 c,d ; dan Areni and Kim, 1994), lebar koridor (Wee and Tong, 2007; Kusumowidagdo et al., 2012 c,d), lift dan escalator (Wee and Tong, 2007; Kusumowidagdo et al., 2012 c, d), ketinggian lantai (Kusumowidagdo, et al, 2012 c, d), material pelingkup (Kusumowidagdo et al. 2012 c, d), void dan atrium (Kusumowidagdo et al., $2012 \mathrm{c}$, d), tata letak toko (Wee and Tong, 2007; Kusumowidagdo et al., 2012 d), visibility lobby 
pusat belanja dan kenyamanan lobby pusat belanja (Kusumowidagdo et al., 2012 d), di mana keseluruhan indicator ini memiliki pengaruh terhadap respon pengunjung terhadap lingkungan pusat belanja.

Selanjutnya pada fasilitas penunjang merupakan faktor penting selain fitur arsitektur dan interior (Kusumowidagdo et al., 2012 d). Indikator yang dipertimbangkan oleh pengunjung untuk dapat beraktifitas adalah kenyamanan lokasi (Kramer, 2008, Wee and Tong, 2007, Kusumowidagdo et al., 2012), parkir (Wee and Tong, 2007; Pinto and Leonidas, 1994; Kramer, 2008; Kusumowidagdo et al., 2012 c, d), kebersihan umum dan toilet (Pinto and Leonidas, 1994; Kusumowidagdo, 2010; Kusumowidagdo et al., 2012 d), keragaman penyewa (Wee and Tong, 2007, Kusumowidagdo et al., 2012c, d) dan media promosi (Wee and Tong, 2007).

Dalam penelitian Kusumowidagdo et al. (2012 a), telah dibuktikan bahwa pusat belanja yang berada dalam tahap daur hidup pengenalan (introduction) memiliki lingkungan belanja yang dipersepsi lebih baik daripada pusat belanja dengan dalam kondisi matur.

Pengelolaan atmosfer pusat belanja tidak dapat dilepaskan dari fakta pusat belanja masa kini yangsecara bersamaan memiliki fungsi sebagai media fungsional dan experential sebagai sebuah produk budaya konsumsi (Siregar, 1998). Sebagai media fungsional atmosfer akan mewadahi kegiatan transaksional secara fungsional secara tiga dimensi, sedangkan secara experential, atmosfer harus dapat memberikan suasana yang mendukung proses berbelanja tersebut, sehingga timbul perasaan senang dan bergairah pada lingkungan belanja. Lingkungan belanja sebagai tempat terjadinya interaksi antara retailer, produk dan pengunjung akan melibatkan faktor emosi pada pengunjung saat mengapresiasinya (Pellegrini, 2001 pada Spena et al., 2012; Coddelupi, 2001 pada Spena et al., 2012; Castaldo and Mauri, 2008). Faktor relasi inilah yang melatarbelakangi pihak manajemen pusat belanja untuk membangun strategi berdasar atas hiburan, desain, customer involvement dan sensory attributes yang sangat potensial untuk membangun value bagi pengunjung (Fox and Sethuraman, 2006; Grewal and Lewy, 2007). Sehingga nyatalah, pusat belanja tampil sebagai media fungsional dan experential (Sands et al., 2010).
Pada penelitian-penelitian selanjutnya terungkap, terdapat dua tipe shopping value, yakni utilitarian dan hedonic. Utilitarian shopping value dapat didefinisikan sebagai nilainilai belanja yang diperolehsebagai fungsi utama belanja saat mengunjungi toko seperti mendapatkan informasi produk dan mendapatkan produk. Pengunjung mendapatkan utilitarian shopping value dengan memanfaatkan desain lingkungan belanja/atmosfer sebagai media fungsional.

Sedangkan hedonic value adalah nilainilai yang diperoleh konsumen untuk bersenang-senang dan menikmati pusat belanja. Dalam hal ini pengunjung mendapatkan hedonic value dengan memanfaatkan desain lingkungan belanja/atmosfer sebagai media eksperential.

Dimensi nilai ini telah diteliti dan berpengaruh pada perilaku dalam pusat belanja (Kaltcheva dan Weitz, 2006), dan dipengaruhi pula oleh atmosfer pusat belanja (Sands et al., 2010). Pengalaman berbelanja dengan lima dimensi, sense, merasakan, berpikir, bertindak dan mengkondisikan dengan lingkungan (Schmidtt, 1999) menjadi kerangka logis untuk menghubungkan konteks penelitian ini yaitu atmosfer pusat belanja dan shopping value (pusat belanjasebagai media fungsional yang memberikan utilitarian value, dan pusat belanja sebagai media eksperensial yang memberikan hedonic value). Kedua nilai tersebut baik utilitarian dan hedonic merupakan aspek yang tidak dapat terpisahkan, dan dirasakan secara simultan dalam atmosfer pusat belanja. (Fiore dan Ogle, 2000 pada Fiore 2008; Kusumowidagdo, 2012; Kusumowidagdo, 2013 b). Atmosfer pusat belanja menjadi stimuli bagi pengunjung untuk berespon (Mehrabian and Russel, 1978, Donovan and Rossiter, 1982 serta Turley and Milliman, 2000).

Berdasarkan literatur di atas pengalaman berbelanja yang dipengaruhi oleh estetika atmosfer yang berdasar pada fungsi transaksi dan eksperensial mendorong perilaku konsumen. Sehingga hipotesis yang diajukan dalam penelitian ini adalah sebagai berikut:

H1: Architectural features, interior features dan support facilities secara serempak berpengaruh terhadap shopping value.

$\mathrm{H} 2$ : Architectural features, interior features dan support facilities secara parsial berpengaruh terhadap shopping value. 


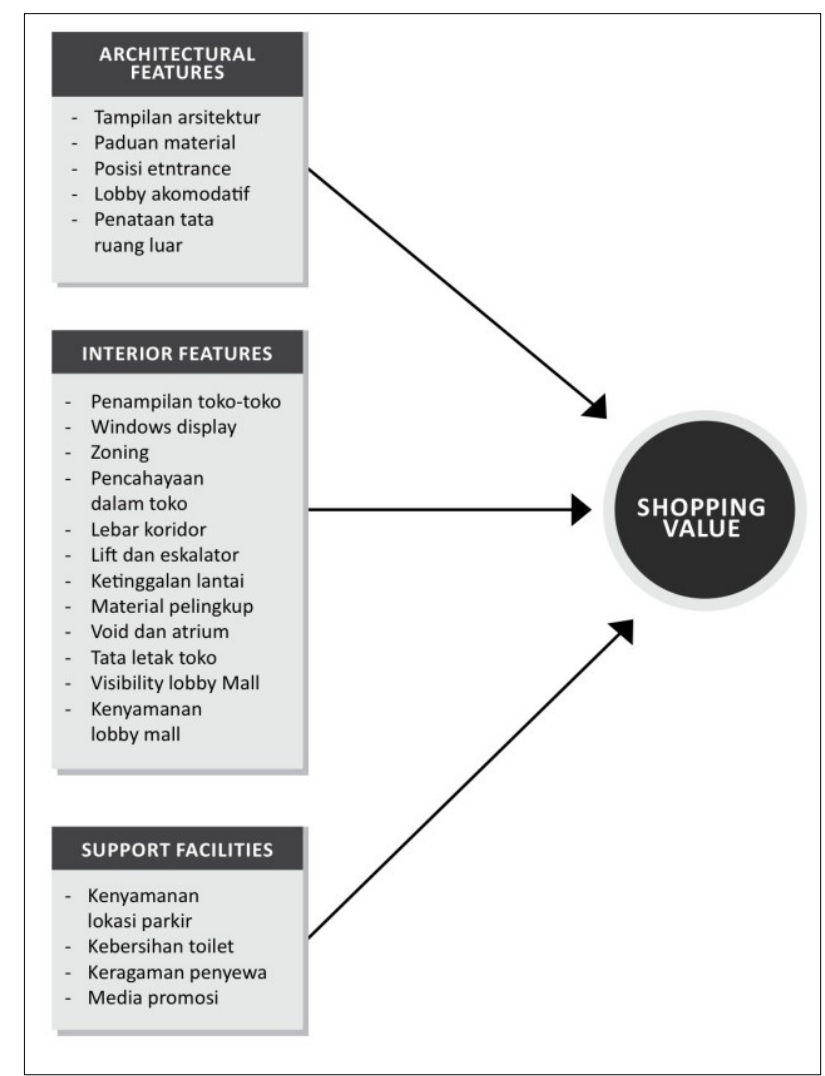

Gambar 2: Hubungan antara Atmosfer Pusat Belanja Terhadap Shopping Value (Sumber: Modifikasi dari model terdahulu pada Kusumowidago et al., 2012a)

\section{METODE PENELITIAN}

\section{Populasi dan Sampel}

Populasi yang dimaksudkan dalam penelitian ini adalah konsumen yang memilih masuk, mengunjungi pusat belanja, telah berkunjung lebih dari 2 kali pada pusat belanja dan dapat menyebutkan identitas fisik pusat belanja. Jumlah anggota populasi adalah sangat besar dan tidak dapat diketahui dengan tepat berapa jumlahnya, dan dalam penelitian ini pengambilan sampel dilakukan dengan mempertimbangkan bahwa populasi yang sangat besar tidak memungkinkan untuk menelitii seluruh populasi yang ada. Sampel adalah non propability sampling, di mana setiap unsur dalam populasi tidak memiliki kesempatan yang sama untuk dipilih sebagai sampel bahkan probabilitas anggota populasi tertentu untuk terpilih tidak diketahui, maka dalam penelitian ini menggunakan sampel sebanyak 60 orang. Secara spesifik sampel yang dipilih termasuk di dalam usia 18-35 tahun yang secara psikologis berada pada tahap dewasa muda dan fase high achievement (Papalia, 2008)

\section{Obyek Penelitian}

Penelitian bertempat di Jakarta sebagai kota utama Indonesia yang memiliki pusat belanja dengan jumlah terbanyak. Untuk pemilihan pusat belanja dipertimbangan jenis pusat belanja dengan aksesibilitas data yang dapat diambil, umur pusat belanja yang berada di atas tahun 1998 karena memiliki daya tarik fisik yang lebih besar (Kusumowidagdo et al., 2012 a). Pusat belanja terpilih adalah Senayan City di kawasan Jakarta Selatan.

\section{Variabel-Variabel Penelitian}

Penelitian ini mempergunakan data primer dari hasil kuesioner yang disebarkan langsung dan observasi di lapangan. Kuesioner ini dipergunakan untuk menguji variabel-variabel penelitian yang digunakan dalam penelitian ini. Variabel-variabel dalam penelitian ini mengacu pada penelitian Kusumowidagdo et al. (2012 a), yang kemudian indikator-indikator telah ditemukan melalui focus group discussion, dalah sebagai berikut: 1) Architectural Features $(A F)$, yakni elemen elemen arsitektur 
yang membentuk atmosfer lingkungan belanja, yang meliputi tampilan arsitektur, paduan material, posisi entrance, lobby dan penataan ruang luar. 2 Interior Features (IF), yakni elemen interior yang membentuk atmosfer lingkungan belanja, seperti penampilan toko/ruang penyewa, windows display, zoning, pencahayaan dalam toko, lebar koridor, keberadaan lift dan escalator, ketinggian lantai, material pelingkup, void dan atrium, tata letak toko, visibility lobby pusat belanja, dan kenyamanan lobby pusat belanja. 3) Support Facilities $(S F)$, yakni fasilitas penunjang yang turut membentuk atmosfer lingkungan yakni kenyamanan, lokasi parkir, kebersihan toilet, keragaman penyewa, dan media promosi. 4) Shopping Value $(S V)$ yakni nilai yang didapat customer dalam berbelanja yaitu kesesuaian harga, kelengkapan berbelanja, kesesuaian suasana dengan level kelas ekonomi, dan kesesuaian suasana dengan gaya hidup.

Masing-masing variabel di atas diukur dengan skala Likert 5 point yaitu sangat tidak baik (1), tidak baik (2), cukup baik (3), baik (4) dan sangat baik (5). Untuk validitas dan reliabilitas, variabel-variabel ini telah diuji dengan confirmatory factor analysis, yang bertujuan agar indikator dapat bertindak semaksimal mungkin dalam fungsinya untuk mengukur variabel. Dengan hasil analisis yang menunjukkan semua pertanyaan pada indikator menunjukkan factor loading lebih dari 0,30 (Hair et al. 2006) sehingga dapat dikatakan valid. Sedangkan realibitasnya diukur dengan mempergunakan Cronbach's Alpha dan Corrected Item to total Correlation yang dapat menunjukkan konsistensi instrument, dengan hasil yang telah memenuhi uji reliabilitas dengan alpha $>0.50$ (Hair et al., 2006).

\section{Metode Analisis Data}

Penelitian ini mempergunakan teknik analisa regresi linier berganda. Hairet et al. (2006) menjelaskan bahwa analisis regresi juga merupakan alat statistik yang seharusnya digunakan ketika baik variabel bebas dan tergantung adalah metrik. Oleh karena itu model regresi berganda digunakan untuk mengetahui pengaruh faktor-faktor pembentuk atmosfer pusat belanja pada shopping value di pusat belanja. Spesifikasi yang dipergunakan dalam penelitian ini adalah sebagai berikut:
$\mathrm{Y}=\mathrm{a}+\mathrm{b} 1 \mathrm{x} 1+\mathrm{b} 2 \times 2+\mathrm{b} 3 \times 3+\mathrm{b} 4 \times 4+e$

Keterangan

Y: Shopping Value

A: Konstanta

b1,b2,b3,b4,b5 : Koefisien regresi

$\mathrm{x} 1$ :Persepsi atas fitur arsitektur (architectural features)

x2:Persepsi atas fitur interior (interior features)

$\mathrm{x} 3$ :Persepsi atas fasilitas penunjang (support facilities)

e: Koefisien pengganggu

Uji statistik yang dipergunakan adalah uji asumsi klasik, analisis regresi,uji t,dan uji F. Uji asumsi klasik dimaksudkan untuk mengetahui apakah penggunaan model regresi linier berganda yang dihgunakan tersebut telah memenuhi asumsi klasik tersebut dengan uji distribusi normal, uji multikolinearitas, uji linearitas dan uji heteroskesdasitas. Uji F yang dipergunakan untuk mengetahui pengaruh variabelvaribel bebas terhadap tergantung secara bersama-sama. Penilaian dapat dilkaukan dengan tingkat signifikansi lebih kecil dari $5 \%$ dikatakan terdapat pengaruh antara variabel-variabel pusat belanja atmosphere terhadap shopping value. Lalu, uji t yang dilakukan untuk menguji variabel-variabel bebas terhadap variabel tergantung secara parsial. Jika signifikansinya lebih kecil dari $5 \%$ maka dikatakan ada pengaruh yang berarti dari variabel bebas terhadap variabel tergantungnya.

\section{HASIL ANALISIS DAN PEMBAHASAN}

Hasil analisis dan pembahasan akan terbagi menjadi analisa deskriptif, uji validitas dan realibilitas, uji asumsi klasik, pengujian model regresi, koefisien determinasi, pengujian hipotesis simultan, pengujian hipotesis parsial dan pembahasan.

\section{Analisis Deskriptif}

Analisis deskriptif digunakan untuk menganalisis data dengan mendeskripsikan atau menggambarkan data yang telah terkumpul sebagaimana adanya. Berikut disajikan analisis deskriptif variabel architectural features, interior features, support facilites dan shopping value di pusat belanja Senayan City. Tabel 1 berikut menggambarkan variabel pertama, 
tanggapan responden pada architectural features.

Dari tabel 1 dapat dilihat perolehan skor dari tanggapan responden mengenai architectural features di Pusat belanja Senayan City, dari lima item pernyataan di atas dapat dilihat perolehan skor tertinggi sebesar 213 terdapat pada pernyataan nomor 5 mengenai penataan tata ruang luar yang indah, sedangkan skor terendah sebesar 226 terdapat pada pernyataan nomor 3 mengenai posisi entrance yang mudah terlihat.

Sedangkan untuk perolehan skor secara keseluruhan mengenai variabel architectural features adalah sebesar 1098 termasuk dalam kategori baik, hal ini ditunjukan dari skor yang berada pada rentang interval antara 1020-1260. Jika di gambarkan dalam garis kontinum maka akan nampak sebgaimana gambar 3 .

Dari tabel 2 dapat dilihat perolehan skor dari tanggapan responden mengenai interior features di Pusat belanja Senayan City, dari ketiga belas item pernyataan di atas dapat dilihat perolehan skor tertinggi sebesar 235 terdapat pada pernyataan nomor 5 mengenai pencahayaan pada pusat belanja (diluar toko) yang baik, sedangkan skor terendah sebesar 210 terdapat pada pernyataan nomor 13 mengenai lobby pusat belanja yang elegan dan nyaman.

Sedangkan untuk perolehan skor secara keseluruhan mengenai variabel interior features di Pusat belanja Senayan City adalah sebesar 2914 termasuk dalam kategori baik, hal ini ditunjukan dari skor yang berada pada rentang interval antara 2652 - 3276. Jika di gambarkan dalam garis kontinum maka akan nampak sebagaimana Gambar 4.

Dari tabel 3 tersebut terlihat bahwa perolehan skor dari tanggapan responden mengenai support facilities di Pusat belanja Senayan City, dari keempat item pernyataan di atas dapat dilihat perolehan skor tertinggi sebesar 237 terdapat pada pernyataan nomor 1 mengenai lokasi parkir yang nyaman, sedangkan skor terendah sebesar 218 terdapat pada pernyataan nomor 3 mengenai penyewapenyewa yang cukup beragam dan lengkap.

Sedangkan untuk perolehan skor secara keseluruhan mengenai variabel support facilities adalah sebesar 904 termasuk dalam kategori baik, hal ini ditunjukan dari skor yang berada pada rentang interval antara 816-1008. Jika di gambarkan dalam garis kontinum maka akan nampak sebagaimana Gambar 5 .

Tabel 1: Tanggapan Responden Mengenai Architectural Features

\begin{tabular}{|c|c|c|c|c|c|c|c|c|c|}
\hline \multirow{2}{*}{ No } & \multirow{2}{*}{ Pernyataan } & \multicolumn{6}{|c|}{ Frekuensi } & \multirow{2}{*}{$\begin{array}{c}\text { Skor } \\
\text { Aktual }\end{array}$} & \multirow{2}{*}{$\begin{array}{l}\text { Skor } \\
\text { Ideal }\end{array}$} \\
\hline & & & 5 & 4 & 3 & 2 & 1 & & \\
\hline \multirow[t]{2}{*}{1} & Tampilan arsitektur menarik & $\mathrm{F}$ & 1 & 37 & 22 & 0 & 0 & \multirow{2}{*}{219} & \multirow{2}{*}{300} \\
\hline & & $\%$ & 1,67 & 61,7 & 36,7 & 0 & 0 & & \\
\hline \multirow[t]{2}{*}{2} & Padanan material eksteriortepat & $\mathrm{F}$ & 3 & 37 & 20 & 0 & 0 & \multirow{2}{*}{223} & \multirow{2}{*}{300} \\
\hline & & $\%$ & 5 & 61,7 & 33,3 & 0 & 0 & & \\
\hline \multirow[t]{2}{*}{3} & Posisi Entrance yang mudah terlihat & $\mathrm{F}$ & 8 & 35 & 12 & 5 & 0 & \multirow{2}{*}{226} & \multirow{2}{*}{300} \\
\hline & & $\%$ & 13,3 & 58,3 & 20 & 8,33 & 0 & & \\
\hline \multirow[t]{2}{*}{4} & Lobby yang akomodatif & $\mathrm{F}$ & 1 & 37 & 20 & 2 & 0 & \multirow{2}{*}{217} & \multirow{2}{*}{300} \\
\hline & & $\%$ & 1,67 & 61,7 & 33,3 & 3,33 & 0 & & \\
\hline \multirow[t]{3}{*}{5} & Penataan tata ruang luar yang indah & $\mathrm{F}$ & 2 & 33 & 21 & 4 & 0 & \multirow{2}{*}{213} & \multirow{2}{*}{300} \\
\hline & & $\%$ & 3,33 & 55 & 35 & 6,67 & 0 & & \\
\hline & Total & & & & & & & 1098 & 1500 \\
\hline
\end{tabular}

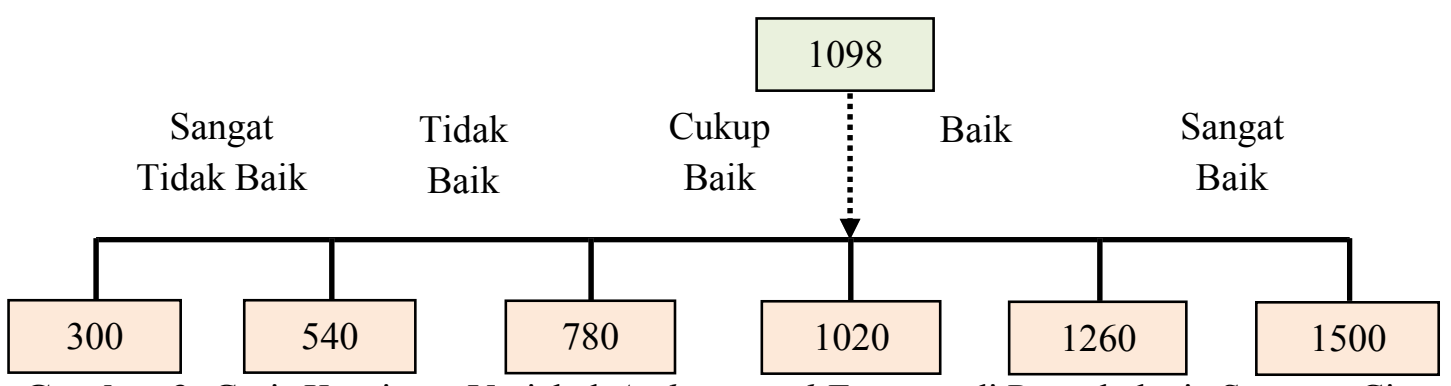

Gambar 3: Garis Kontinum Variabel Architectural Features di Pusat belanja Senayan City 
Tabel 2: Tanggapan Responden Mengenai Interior Features

\begin{tabular}{|c|c|c|c|c|c|c|c|c|c|}
\hline \multirow{2}{*}{ No } & \multirow{2}{*}{ Pernyataan } & & \multicolumn{5}{|c|}{ Frekuensi } & \multirow{2}{*}{$\begin{array}{l}\text { Skor } \\
\text { Aktual }\end{array}$} & \multirow{2}{*}{$\begin{array}{l}\text { Skor } \\
\text { Ideal }\end{array}$} \\
\hline & & & 5 & 4 & 3 & 2 & 1 & & \\
\hline \multirow{2}{*}{1} & & $\mathrm{~F}$ & 5 & 37 & 17 & 1 & 0 & & \\
\hline & Penampilan toko-toko yangdengan display & $\%$ & 8,33 & 61,7 & 28,3 & 1,67 & 0 & 226 & 300 \\
\hline \multirow{2}{*}{2} & Windows disnlay vano menarik dan variatif (nada toko) & $\mathrm{F}$ & 3 & 43 & 12 & 2 & 0 & & \\
\hline & Windows display yang menarık dan variatıf (pada toko) & $\%$ & 5 & 71,7 & 20 & 3,33 & 0 & ? & 300 \\
\hline \multirow{2}{*}{3} & Pengelompokan toko yang yang tepat/zoning & $\mathrm{F}$ & 5 & 28 & 22 & 5 & 0 & 13 & 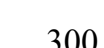 \\
\hline & & $\%$ & 8,33 & 46,7 & 36,7 & 8,33 & 0 & 213 & 30 \\
\hline 4 & Pencahayaan dalam toko yang tepat (dalam toko-toko) & $\mathrm{F}$ & 6 & 39 & 14 & 1 & 0 & 230 & 300 \\
\hline \multirow[b]{2}{*}{5} & & $\%$ & 10 & 65 & 23,3 & 1,67 & 0 & & \\
\hline & Pencahayaan pada mall (diluar toko) yang baik & $\mathrm{F}$ & 128 & 40 & 11 & 1 & 0 & 235 & 300 \\
\hline \multirow{2}{*}{6} & & $\mathrm{~F}$ & 2 & 36 & 16 & 5 & 1 & & \\
\hline & Lebar Jalur koridor yang lelu & $\%$ & 3,33 & 60 & 26,7 & 8,33 & 1,67 & 213 & 300 \\
\hline \multirow{2}{*}{7} & & $\mathrm{~F}$ & 6 & 38 & 16 & 0 & 0 & 30 & \\
\hline & ukup mudah dijangkau & $\%$ & 10 & 63,3 & 26,7 & 0 & 0 & 230 & 300 \\
\hline \multirow[t]{2}{*}{8} & Ketinggian lantai ke langit-langit yangnyaman & $\mathrm{F}$ & 4 & 38 & 18 & 0 & 0 & 226 & 300 \\
\hline & & $\%$ & 6,67 & 63,3 & 30 & 0 & 0 & & \\
\hline 9 & Material bidang pelingkup interior yang baik & $\mathrm{F}$ & 2 & 44 & 11 & 3 & 0 & 225 & 300 \\
\hline \multirow[b]{2}{*}{10} & & $\%$ & 3,33 & 73,3 & 18,3 & 5 & 0 & & \\
\hline & cukup memberikan arah orientasi & $\begin{array}{l}\mathrm{F} \\
0\end{array}$ & $\begin{array}{r}1 \\
167\end{array}$ & 43 & 10 & 833 & 167 & 218 & 300 \\
\hline \multirow{2}{*}{11} & Tata letak toko yang jelas & $\mathrm{F}$ & 5 & 45 & 8 & 2 & 0 & 2 & 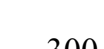 \\
\hline & I ata letak toko yang jelas & $\%$ & 8,33 & 75 & 13,3 & 3,33 & 0 & 33 & 300 \\
\hline 2 & Posisi lobby mall mudah terlihat & $\mathrm{F}$ & 7 & 34 & 19 & 0 & 0 & 228 & 300 \\
\hline \multirow{3}{*}{1.} & & $\begin{array}{l}\% \\
\mathrm{~F}\end{array}$ & 11,7 & $\begin{array}{r}56,7 \\
30\end{array}$ & $\begin{array}{r}31,7 \\
27\end{array}$ & 0 & 0 & & \\
\hline & Lobby mall yang elegan dan nyaman & $\%$ & $\begin{array}{r}1 \\
1,67\end{array}$ & $\begin{array}{l}30 \\
50\end{array}$ & 45 & 3,33 & 0 & 210 & 300 \\
\hline & Tota & & & & & & & 2914 & 3900 \\
\hline
\end{tabular}

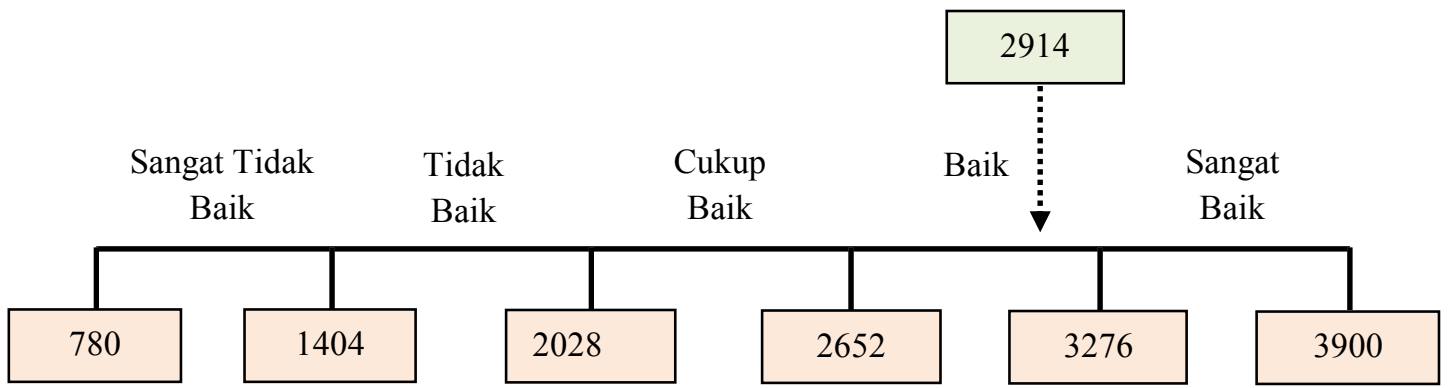

Gambar 4: Garis Kontinum Variabel Interior Featuresdi Pusat belanja Senayan City

Tabel 3: Tanggapan Responden Mengenai Support Facilites

\begin{tabular}{|c|c|c|c|c|c|c|c|c|c|}
\hline \multirow{2}{*}{ No } & \multirow{2}{*}{ Pernyataan } & & \multicolumn{5}{|c|}{ Frekuensi } & \multirow{2}{*}{$\begin{array}{c}\text { Skor } \\
\text { Aktual }\end{array}$} & \multirow{2}{*}{$\begin{array}{l}\text { Skor } \\
\text { Ideal }\end{array}$} \\
\hline & & & 5 & 4 & 3 & 2 & 1 & & \\
\hline 1 & Lokasi parkir yang nyaman & $\begin{array}{l}\mathrm{F} \\
\%\end{array}$ & $\begin{array}{c}7 \\
11,7\end{array}$ & $\begin{array}{c}44 \\
73,3\end{array}$ & $\begin{array}{c}8 \\
13,3\end{array}$ & $\begin{array}{c}1 \\
1,67\end{array}$ & $\begin{array}{l}0 \\
0\end{array}$ & 237 & 300 \\
\hline 2 & Toilet yang bersih dan memadai & $\begin{array}{l}\mathrm{F} \\
\%\end{array}$ & $\begin{array}{c}4 \\
6,67\end{array}$ & $\begin{array}{c}37 \\
61,7\end{array}$ & $\begin{array}{l}18 \\
30\end{array}$ & $\begin{array}{c}1 \\
1,67\end{array}$ & $\begin{array}{l}0 \\
0\end{array}$ & 224 & 300 \\
\hline 3 & Penyewa-penyewa yang cukup beragam dan lengkap & $\begin{array}{l}\mathrm{F} \\
\%\end{array}$ & $\begin{array}{c}5 \\
8,33\end{array}$ & $\begin{array}{l}30 \\
50\end{array}$ & $\begin{array}{c}23 \\
38,3\end{array}$ & $\begin{array}{c}2 \\
3,33\end{array}$ & $\begin{array}{l}0 \\
0\end{array}$ & 218 & 300 \\
\hline 4 & $\begin{array}{l}\text { Media promosi yang memberikan informasi pada } \\
\text { pengunjung }\end{array}$ & $\begin{array}{l}\mathrm{F} \\
\%\end{array}$ & $\begin{array}{c}10 \\
16,7\end{array}$ & $\begin{array}{l}27 \\
45 \\
\end{array}$ & $\begin{array}{l}21 \\
35\end{array}$ & $\begin{array}{c}2 \\
3,33 \\
\end{array}$ & $\begin{array}{l}0 \\
0\end{array}$ & 225 & 300 \\
\hline & Total & & & & & & & 904 & 1200 \\
\hline
\end{tabular}




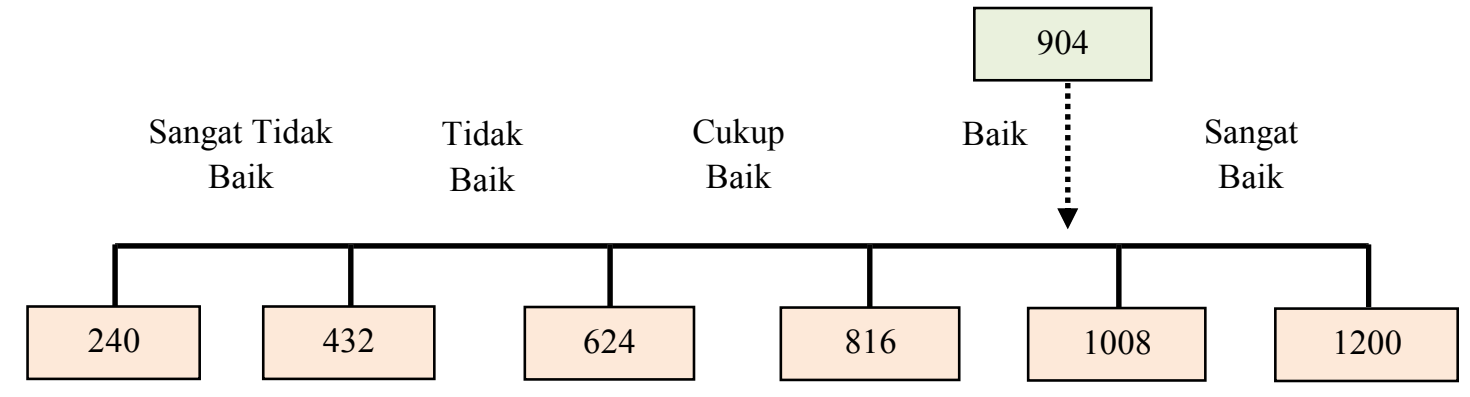

Gambar 5: Garis Kontinum Variabel Support Facilites di Pusat belanja Senayan City

Tabel 4: Tanggapan Responden Mengenai Shopping Value

\begin{tabular}{|c|c|c|c|c|c|c|c|c|c|}
\hline \multirow{2}{*}{ No } & \multirow{2}{*}{ Pernyataan } & & \multicolumn{5}{|c|}{ Frekuensi } & \multirow{2}{*}{$\begin{array}{l}\text { Skor } \\
\text { Aktual }\end{array}$} & \multirow{2}{*}{$\begin{array}{l}\text { Skor } \\
\text { Ideal }\end{array}$} \\
\hline & & & 5 & 4 & 3 & 2 & 1 & & \\
\hline \multirow{2}{*}{1} & \multirow{2}{*}{$\begin{array}{l}\text { Saya belanja di pusat belanja ini dengan harga yang } \\
\text { sesuai }\end{array}$} & $\mathrm{F}$ & 11 & 26 & 21 & 2 & 0 & \multirow{2}{*}{226} & \multirow{2}{*}{300} \\
\hline & & $\%$ & 18,3 & 43,3 & 35 & 3,33 & 0 & & \\
\hline \multirow{2}{*}{2} & \multirow{2}{*}{ Saya bisa belanja barang dengan nyaman dan komplit } & $\mathrm{F}$ & 10 & 30 & 20 & 0 & 0 & \multirow{2}{*}{230} & \multirow{2}{*}{300} \\
\hline & & $\%$ & 16,7 & 50 & 33,3 & 0 & 0 & & \\
\hline \multirow{2}{*}{3} & \multirow{2}{*}{$\begin{array}{l}\text { Saya dapat melakukan berbagai aktivitas selain } \\
\text { belanja di mall }\end{array}$} & $\mathrm{F}$ & 7 & 32 & 18 & 3 & 0 & \multirow{2}{*}{223} & \multirow{2}{*}{300} \\
\hline & & $\%$ & 11,7 & 53,3 & 30 & 5 & 0 & & \\
\hline \multirow{2}{*}{4} & Suasana merasakan bahwa saya memiliki level kelas & $\mathrm{F}$ & 6 & 42 & 8 & 4 & 0 & \multirow{2}{*}{230} & \multirow{2}{*}{300} \\
\hline & $\begin{array}{l}\text { yangyang sama dengan pengunjung-pengunjung } \\
\text { lainnya }\end{array}$ & $\%$ & 10 & 70 & 13,3 & 6,67 & 0 & & \\
\hline \multirow{3}{*}{5} & Suasana dan barang-barangyang dijual cocok dengan & $\mathrm{F}$ & 9 & 33 & 15 & 3 & 0 & \multirow{2}{*}{228} & \multirow{2}{*}{300} \\
\hline & gaya hidup saya & $\%$ & 15 & 55 & 25 & 5 & 0 & & \\
\hline & Total & & & & & & & 1137 & 1500 \\
\hline
\end{tabular}

Dari tabel 4 dapat dilihat perolehan skor dari tanggapan responden mengenai shopping valuedi Pusat belanja Senayan City, dari kelima item pernyataan di atas dapat dilihat perolehan skor tertinggi sebesar 230 terdapat pada pernyataan nomor 2 mengenai kenyamanan dan kelengkapan belanja barang dan nomor 4 mengenai suasana yang membuat kesetaraan level dengan pengunjung-pengunjung lain, sedangkan skor terendah sebesar 223 terdapat pada pernyataan nomor 3 mengenai aktivitas lain yang dapat dilakukan di pusat belanja selain berbelanja.

Sedangkan untuk perolehan skor secara keseluruhan mengenai variabel shopping value adalah sebesar 1137 termasuk dalam kategori baik, hal ini ditunjukan dari skor yang berada pada rentang interval antara 816 - 1008. Jika di gambarkan dalam garis kontinum maka akan nampak sebagaimana gambar 6 .

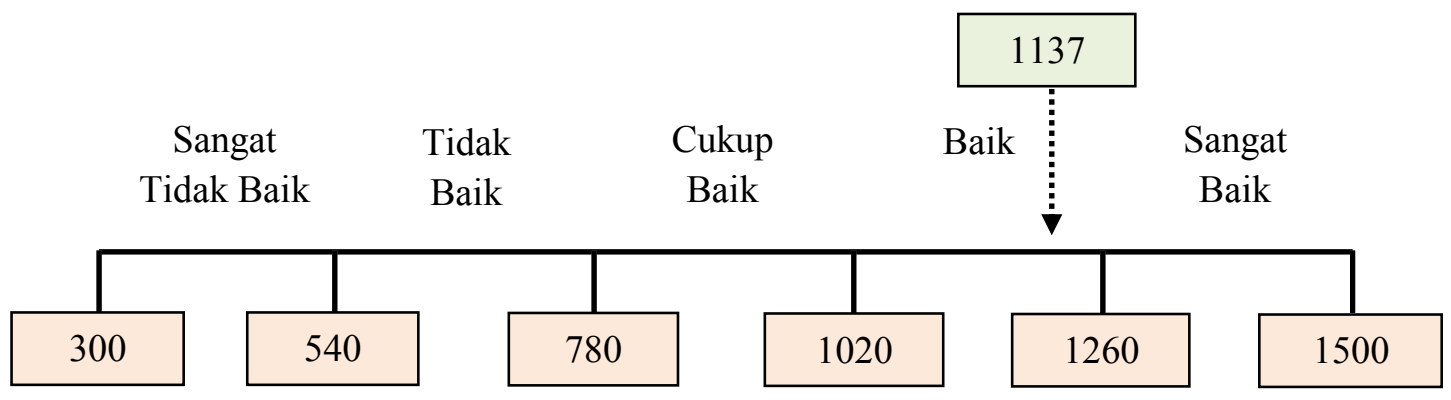

Gambar 6: Garis Kontinum Variabel Sopping Value di Pusat belanja Senayan City 


\section{Uji Validitas dan Realibilitas}

Tabel 5: Uji Validitas dan Realibiltas

\begin{tabular}{|c|c|c|c|c|c|c|c|}
\hline Variabel & $\begin{array}{l}\text { No } \\
\text { Item }\end{array}$ & $\begin{array}{l}\text { Koefisien } \\
\text { Validitas }\end{array}$ & $\begin{array}{l}\text { Titik } \\
\text { Kritis } \\
\end{array}$ & Kesimpulan & $\begin{array}{c}\text { Koefisien } \\
\text { Reliabilitas }\end{array}$ & $\begin{array}{c}\text { Titik } \\
\text { Kritis } \\
\end{array}$ & Kesimpulan \\
\hline \multirow{5}{*}{$\begin{array}{c}\text { Architectural } \\
\text { Features }\end{array}$} & 1 & 0,504 & 0,300 & Valid & \multirow{5}{*}{0,734} & \multirow{5}{*}{0,600} & \multirow{5}{*}{ Reliabel } \\
\hline & 2 & 0,804 & 0,300 & Valid & & & \\
\hline & 3 & 0,743 & 0,300 & Valid & & & \\
\hline & 4 & 0,695 & 0,300 & Valid & & & \\
\hline & 5 & 0,725 & 0,300 & Valid & & & \\
\hline \multirow{13}{*}{$\begin{array}{l}\text { Interior } \\
\text { Features }\end{array}$} & 6 & 0,449 & 0,300 & Valid & \multirow{14}{*}{0,836} & \multirow{14}{*}{0,600} & \multirow{14}{*}{ Reliabel } \\
\hline & 7 & 0,598 & 0,300 & Valid & & & \\
\hline & 8 & 0,721 & 0,300 & Valid & & & \\
\hline & 9 & 0,642 & 0,300 & Valid & & & \\
\hline & 10 & 0,556 & 0,300 & Valid & & & \\
\hline & 11 & 0,536 & 0,300 & Valid & & & \\
\hline & 12 & 0,476 & 0,300 & Valid & & & \\
\hline & 13 & 0,715 & 0,300 & Valid & & & \\
\hline & 14 & 0,712 & 0,300 & Valid & & & \\
\hline & 15 & 0,674 & 0,300 & Valid & & & \\
\hline & 16 & 0,424 & 0,300 & Valid & & & \\
\hline & 17 & 0,657 & 0,300 & Valid & & & \\
\hline & 18 & 0,383 & 0,300 & Valid & & & \\
\hline \multirow{5}{*}{$\begin{array}{c}\text { Support } \\
\text { Facilities }\end{array}$} & 19 & 0,501 & 0,300 & Valid & & & \\
\hline & 20 & 0,761 & 0,300 & Valid & \multirow{3}{*}{0,669} & \multirow{4}{*}{0,600} & \multirow{3}{*}{ Reliabel } \\
\hline & 21 & 0,776 & 0,300 & Valid & & & \\
\hline & 22 & 0,783 & 0,300 & Valid & & & \\
\hline & 23 & 0,804 & 0,300 & Valid & \multirow{5}{*}{0,863} & & \\
\hline \multirow{4}{*}{$\begin{array}{c}\text { Shopping } \\
\text { Value }\end{array}$} & 24 & 0,866 & 0,300 & Valid & & \multirow{4}{*}{0,600} & \multirow{4}{*}{ Reliabel } \\
\hline & 25 & 0,802 & 0,300 & Valid & & & \\
\hline & 26 & 0,792 & 0,300 & Valid & & & \\
\hline & 27 & 0,758 & 0,300 & Valid & & & \\
\hline
\end{tabular}

\section{Uji Asumsi Klasik}

\section{Uji Normalitas}

Berdasarkan tabel 6 di bawah ini, output hasil pengujian normalitas dengan menggunakan Kolmogorov-Smirnov di atas, diperoleh nilai signifikansi (Asymp. Sig. (2-tailed) untuk masing-masing variabel adalah sebesar architectural features (X1) 0,163, interior features
(X2) 0,760, supportt facilities (X3) 0,262 dan shopping value (Y) 0,269. Nilai Asymp. Sig. (2tiled) yang diperoleh masing-masing variabel tersebut memiliki nilai di atas 0,05 sehingga dapat disimpulkan bahwa masing-masing variabel yang digunakan memiliki data yang berdistribusi normal. Dengan kata lain, asumsi normalitas data terpenuhi.

Tabel 6: Uji Normalitas dengan Kolmogorov-Smirnov One-Sample Kolmogorov-Smirnov Test

\begin{tabular}{llcccc}
\hline & & Architectural & Interior & Support & Shopping \\
& & Features (X1) & Features (X2) & Facilites (X3) & Value (Y) \\
\hline $\mathrm{N}$ & & 60 & 60 & 60 & 60 \\
Normal Parameters & Mean & 13,1237 & 39,5344 & 13,4280 & 14,3828 \\
& Std. Deviation & 3,03354 & 6,57219 & 2,53333 & 3,65665 \\
Most Extreme Differences & Absolute &, 144 &, 087 &, 130 &, 129 \\
& Positive &, 117 &, 087 &, 073 &, 123 \\
& Negative &,- 144 &,- 086 &,- 130 &,- 129 \\
Kolmogorov-Smirnov Z & & 1,119 &, 670 & 1,007 & 1,00 \\
Asymp. Sig. (2-tailed) & &, 163 &, 760 &, 262 &, 269 \\
\hline
\end{tabular}

a. Test distribution is normal

b. Calculated from data 


\section{Uji Multikolinieritas}

Berdasarkan tabel 7 di bawah ini, diketahui nilai tolerance untuk kedua variabel bebas $>0,1$ dan Nilai VIF untuk kedua variabel bebas $<10$. Hal ini menunjukan bahwa dari data yang digunakan tidak terjadi multikolinieritas.

\section{Uji Heteroskedastisitas}

Untuk menguji gejala heteroskedastisidas digunakan pengujian dengan menggunakan diagram pencar (scatter plot), Berdasarkan gambar pada Gambar 7, diketahui bahwa titiktitik yang diperoleh tidak membentuk pola tertentu, yang menunjukan bahwa data yang diuji tidak memiliki masalah heteroskedastisitas.

\section{Uji Linearitas}

Dari tabel di atas dapat diketahui bahwa nilai signifikansi pada uji linearitas untuk seluruh variabel bebas adalah sebesar 0,000. Karena signifikansi kurang dari 0,05 maka dapat disimpulkan bahwa antara variabel architectural features (0.001), interior features (0.00) dan support facilities (0.00) terdapat hubungan yang linear. Jika terdapat hubungan yang linear, artinya dapat dilaksanakan regresi untuk tahap selanjutnya.

Berdasarkan uji asumsi yang telah dilakukan, diketahui semua pengujian tidak menghasilkan adanya pelanggaran asumsi klasik. Dengan demikian maka data layak di analisis dengan menggunakan analisis linier berganda.

Tabel 7: Uji Multikolinearitas

Coefficients $^{\mathrm{a}}$

\begin{tabular}{llcc}
\hline & & \multicolumn{2}{c}{ Collinearity Statistics } \\
\cline { 3 - 4 } Model & & Tolerance & VIF \\
\hline 1 & Architectural Features (X1) &, 662 & 1,511 \\
& Interior Features (X2) &, 458 & 2,182 \\
& Support Facilities (X3) &, 530 & 1,885 \\
\hline
\end{tabular}

a. Dependent Variable: Shopping Value (Y)

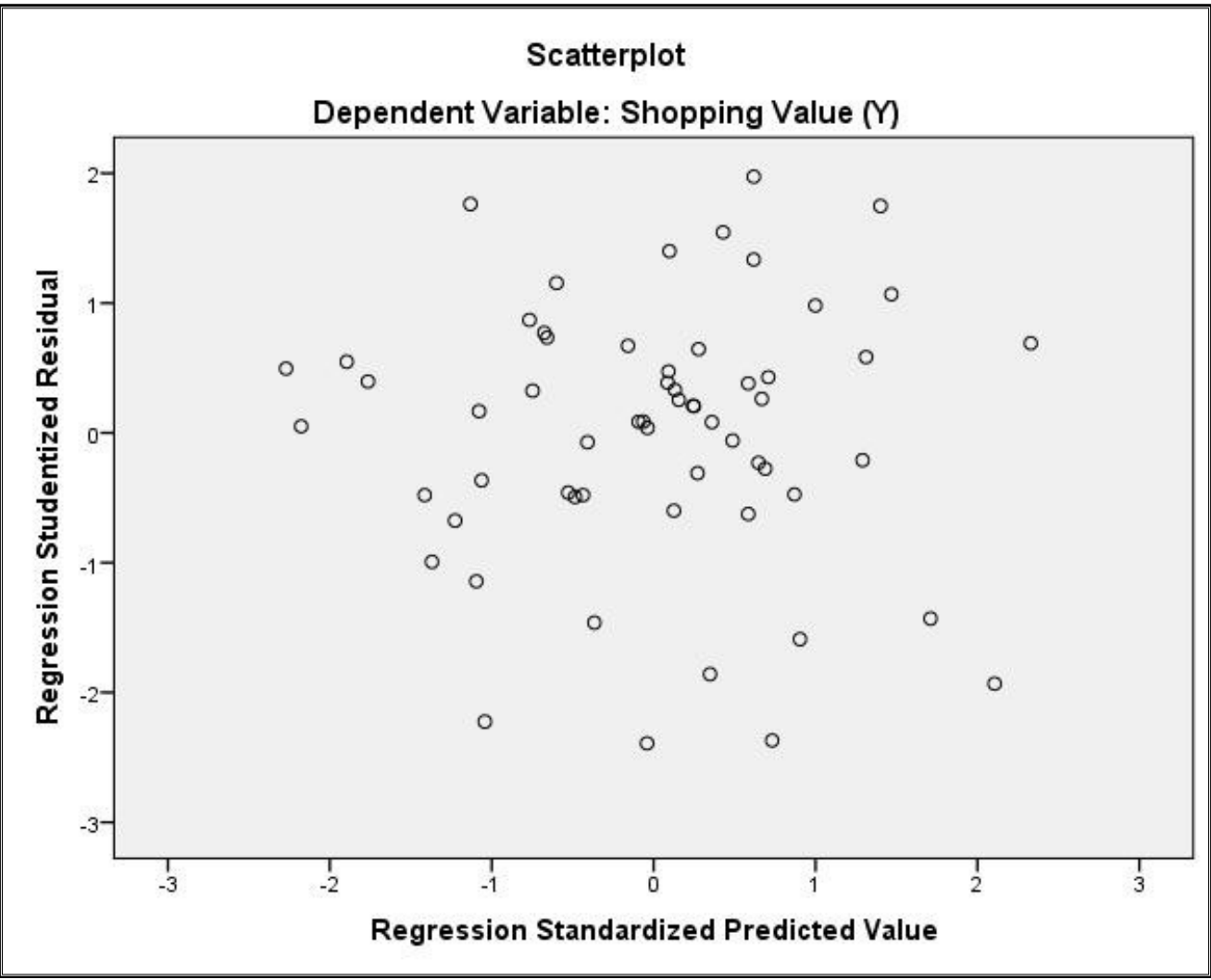

Gambar 7: Diagram Pencar 
Tabel 8: Tes Linearitas dengan SPSS 20

\begin{tabular}{|c|c|c|c|c|c|c|c|}
\hline \multicolumn{8}{|c|}{ ANOVA Table } \\
\hline & & & $\begin{array}{l}\text { Sum of } \\
\text { Squares }\end{array}$ & $\mathrm{df}$ & $\begin{array}{l}\text { Mean } \\
\text { Square }\end{array}$ & $\mathrm{F}$ & Sig. \\
\hline \multirow{5}{*}{$\begin{array}{l}\text { Shopping Value }(\mathrm{Y})^{*} \\
\text { Architectural Features } \\
(\mathrm{X} 1)\end{array}$} & Between Groups & (Combined) & 481,803 & 33 & 14,600 & 1,236 & 291 \\
\hline & & Linearity & 176,029 & 1 & 176,029 & 14,904 & 001 \\
\hline & & Deviation from Linearity & 305,773 & 32 & 9,555 & ,809 & ,718 \\
\hline & Within Groups & & 307,092 & 26 & 11,811 & & \\
\hline & Total & & 788,894 & 59 & & & \\
\hline \multicolumn{8}{|c|}{ ANOVA Table } \\
\hline & & & $\begin{array}{l}\text { Sum of } \\
\text { Squares }\end{array}$ & $\mathrm{df}$ & $\begin{array}{c}\text { Mean } \\
\text { Square }\end{array}$ & $\mathrm{F}$ & Sig. \\
\hline Shopping Value $(\mathrm{Y})^{*}$ & Between Groups & (Combined) & 760,330 & 49 & & & \\
\hline \multirow[t]{4}{*}{ Interior Features (X2) } & & Linearity & 417,110 & 1 & & & \\
\hline & & Deviation from Linearity & 343,220 & 48 & & & \\
\hline & Within Groups & & 28,564 & 10 & & & \\
\hline & Total & & 788,894 & 59 & & & \\
\hline \multicolumn{8}{|c|}{ ANOVA Table } \\
\hline & & & $\begin{array}{c}\text { Sum of } \\
\text { Squares }\end{array}$ & $\mathrm{df}$ & $\begin{array}{l}\text { Mean } \\
\text { Square }\end{array}$ & $\mathrm{F}$ & Sig. \\
\hline Shopping Value $(\mathrm{Y})^{*}$ & Between Groups & (Combined) & 669,088 & 29 & 23,072 & 5,777 & ,000 \\
\hline \multirow[t]{4}{*}{ Support Facilites (X3) } & & Linearity & 273,709 & 1 & 273,709 & 68,538 &, 000 \\
\hline & & Deviation from Linearity & 395,378 & 28 & 14,121 & 3,536 &, 000 \\
\hline & Within Groups & & 119,806 & 30 & 3,994 & & \\
\hline & Total & & 788,894 & 59 & & & \\
\hline
\end{tabular}

\section{Pengujian Model Regresi}

Tabel 9: Analisa Regresi Linear Berganda

Coefficient $^{\mathrm{a}}$

\begin{tabular}{|c|c|c|c|c|c|c|}
\hline \multirow{2}{*}{ Model } & & \multicolumn{2}{|c|}{ Unstandardized Coefficients } & \multirow{2}{*}{$\begin{array}{c}\text { Standardized Coefficients } \\
\text { Beta }\end{array}$} & \multirow{2}{*}{$\mathrm{t}$} & \multirow{2}{*}{ Sig. } \\
\hline & & B & Std. Error & & & \\
\hline \multirow[t]{4}{*}{1} & (Constant) & $-2,574$ & 2,094 & & $-1,229$ & ,224 \\
\hline & Architectural Features (X1) & ,078 & 133 &, 065 &, 587 &, 559 \\
\hline & Interior Features (X2) & 321 & 074 & ,576 & 4,346 &, 000 \\
\hline & Support Facilities (X3) & 242 &, 178 & , 168 & 1,362 &, 179 \\
\hline
\end{tabular}

Hasil analisis regresi linier berganda disajikan pada tabel 9 di atas. Berdasarkan output di atas, diperoleh nilai a sebesar $-2,574$, nilai Dengan demikian maka dapat dibentuk persamaan regresi linier berganda sebagai berikut:

$\mathrm{Y}=-2.574+0,065 \mathrm{X}_{1}+0,576 \mathrm{X}_{2}+0,168 \mathrm{X}_{3}$

Dilihat dari nilai $b_{1} 0,065 b_{2} \quad 0,576$, dan $b_{3}$ 0,168 .Yang positif dapat diartikan bahwa jika variabel persepsi atas architectural features, interior feature dan support facilities yang positif maka dari persamaan tersebut terlihat bahwa persepsi atas shopping value akan positif pula, atau dapat dijelaskan dalam hubungan berbanding lurus.

\section{Pengujian Hipotesis Simultan}

Dalam pengujian hipotesis simultan (hipotesis pertama), untuk menguji apakah architectural features, interior features dan support facilities secara bersama-sama memberikan pengaruh yang signifikan terhadap shopping value, dapat dilihat pada output tabel 10 .

Dari tabel 10 terlihat tingkat signifikansi lebih kecil dari 5\% sehingga dikatakan terdapat pengaruh antara variabel-variabel pusat belanja atmosphere terhadap shopping value. 
Tabel 10: Nilai Uji F

ANOVA $^{\mathrm{a}}$

\begin{tabular}{llccccc}
\hline Model & Sum of Squares & df & Mean Square & F & Sig \\
\hline 1 & Regression & 432,771 & 3 & 144,257 & 22,684 &, $000^{b}$ \\
& Residual & 356,123 & 56 & 6,359 & & \\
& Total & 788,894 & 59 & & & \\
\hline
\end{tabular}

a. Dependent Variabel: Shopping Value (Y)

b. Predictors: (Constant), Support Facilities (X3), Architectural Features (X1), Interior Features (X2)

\section{Pengujian Hipotesis Parsial (Uji t)}

Hipotesis parsial yang dinyatakan dengan $a r-$ chitectural features, interior features dan support facilities secara parsial berpengaruh terhadap shopping value, diuji dengan tingkat signifikansinya. Dengan melihat tingkat signifikansinya, maka hanya interior features (IF) dengan nilai 0.00 (lebih kecil dari $5 \%$ ) maka memberikan pengaruh pada shopping value. Sedangkan architectural features (AF) dan support facilities (SF) yang berturut-turut memiliki nilai 0.559 dan 0.179 dinilai tidak memberikan pengaruh pada shopping value.

\section{Koefisien Determinasi}

Analisis koefisien determinasi digunakan untuk mengetahui seberapa besar kontribusi pengaruh yang diberikan variabel bebas terhadap variabel terikat. Koefisien determinasi atau R-Square merupakan kuadrat dari nilai $\mathrm{R}$ atau nilai korelasi.
Nilai koefisien determinasi atau $R$-Square yang diperoleh 0,549 atau 54,9\%. Tabel 11, di bawah ini akan menjelaskan pernyataan ini.

Selanjutnya, tabel 12 menunjukan bahwa architectural features, interior features dan support facilities secara bersama-sama memberikan kontribusi pengaruh terhadap shopping value sebesar 54,9\%, sedangkan sisanya sebesar $45,1 \%$ merupakan pengaruh variabel lain yang tidak diteliti.

Dari keseluruhan kontribusi dari variabel-variabel atmosfer pusat belanja, dari ketiga variabel yang memberikan pengaruh paling dominan terhadap shopping value dengan kontribusi pengaruh yang diberikan sebesar 57,9\% adalah interior features, kemudian diikuti oleh variabel support facilities sebesar 16,8\%, dan variabel yang memberikan pengaruh terkecil terhadap shopping value adalah architectural features sebesar $6,5 \%$.

Tabel 11: R Square

Model Summary ${ }^{\mathrm{b}}$

\begin{tabular}{lcccc}
\hline Model & $\mathrm{R}$ & $\mathrm{R}$ Square & Adjusted R Square & Std. Error of the Estimate \\
\hline 1 &, $741^{\mathrm{a}}$ &, 549 &, 524 & 2,52177 \\
\hline
\end{tabular}

a. Predictors: (constant), Support Facilities (X3), Architectural Features (X1), Interior Features (X2)

b. Dependent Variable: Shopping Value (Y)

Tabel 12: Kontribusi Variabel Terhadap Shopping Value

\begin{tabular}{llcc}
\hline & & $\begin{array}{c}\text { Standardized } \\
\text { Coefficients }\end{array}$ & Correlations \\
\cline { 2 - 4 } Model & Beta & Zero-order \\
\hline $1 \quad$ Architectural Features (X1) &, 065 &, 472 \\
& Interior Features (X2) &, 576 &, 727 \\
& Support Facilities (X3) &, 168 &, 589 \\
\hline
\end{tabular}

a. Dependent Variable: Shopping Value (Y) 


\section{Pembahasan}

Sehingga sebagai kesimpulan, berdasarkan hasil analisis data dan pembahasan yang telah dilakukan, maka penulis mengambil beberapa kesimpulan. Pertama, secara simultan, architectural features, interior features, support vacilites secara bersama-sama memberikan pengaruh terhadap shopping value di Pusat belanja Senayan City sebesar 54,9\%. Pengaruh yang diberikan ketiga variabel terhadap shopping value di Pusat belanja Senayan City secara terpisah adalah architectural features sebesar $6,5 \%$, interior features sebesar $57,6 \%$ dan support facilities sebesar 16,8\%.Interior features yang menyumbang kontribusi terbesar dikarenakan aktivitas terlama dari para pebelanja adalah dalam ruang interior pusat belanja, sehingga di sini memberikan pengaruh terbesar dibanding lainnya. Sehingga bagi pengelola pusat belanja, dan desainer hendaknya memberikan titik berat pada faktor interior seperti penampilan toko/ruang penyewa, windows display, zoning, pencahayaan dalam toko, lebar koridor, keberadaan lift dan escalator, ketinggian lantai, material pelingkup, void dan atrium, tata letak toko, visibility lobby pusat belanja, dan kenyamanan lobby pusat belanja. Dengan pengelolaan desain dan pengalaman yang diberikan pada ruang interior akan memberikan shopping value yang berarti bagi pengunjung. Sesuai dengan tabel 2, maka nilai terbesar terdapat pada pencahayaan pada pusat belanja dan nilai terkecil terdapat pada kenyamanan lobby pusat belanja. Nilai pencahayaan tersebut, berturut-turut disusul dengan nilai jalur transportasi vertikal dan ketinggian langitlangit. Dari observasi, pencahayaan dinilai penting untuk kemudahan dalam pencarian produk-produk yang diinginkan, meningkatkan persepsi atas nilai produk dan memberikan suasana yang nyaman bagi kegiatan belanja. Sedangkan yang terpenting jalur transportasi vertikal, adalah perletakan dan kapasitas. Perletakan akan memberikan kemudahan pengunjung dalam mengelilingi pusat belanja, dan selanjutnya, kapasitas dinilai penting untuk dapat mengakomodasi jumlah pengunjung pusat belanja untuk dapat beraktivitas dengan tenggat waktu tunggu yang kecil.

Kedua, kecilnya pengaruh nilai architectural features (AF) dan juga support facilities (SF) tidak hanya terlihat pada kontribusinya secara serempak di atas, namun juga pada uji parsial, yang menyatakan architectural features dan support facilities tidak signifikan berpengaruh terhadap shopping value dari pengunjung. Di sini bagi para pengelola pusat belanja, sebenarnya terdapat peluang untuk juga meningkatkan persepsi atas architectural features dan support facilities.

Peningkatan architectural features dapat berupa redesain tampilan arsitektur, paduan material, penguatan posisi entrance, peningkatan kenyamanan lobby dan penataan ruang luar. Untuk pusat belanja ini, nilai yang tertinggi dalam penilaian secara deskriptif adalah posisi entrance. Posisi entrance dalam kasus ini dinilai cukup baik. Posisi entrance yang baik dan mudah dikenali akan berfungsi untuk mempermudah pengunjung dalam mengakses pada lingkungan dalam pusat belanja.

Sedangkan support facilities dapat berupa fasilitas penunjang yang turut membentuk atmosfer lingkungan yakni peningkatan pengelolaan parkir, peningkatan kebersihan toilet, pengelolaan keragaman penyewa, dan peningkatan media promosi. Di antara faktorfaktor support facilities ini pengelolaan parkir berada pada penilaian tertinggi, yang artinya keberadaan ruang parkir yang nyaman pada area ini dipersepsikan baik dan mendukung. Pihak pengelola hendaknya memberikan perhatian pada alokasi kapasitas dan juga perletakan zona parkir merupakan elemen-yang penting dalam hal ini.

Pada shopping value yang didapat, terlihat bahwa terdapat keseimbangan antara faktor-faktor yang mendukung nilai fungsi belanja dan faktor yang mendukung nilai pengalaman (eksperensialnya). Hal ini nampak pada pembahasan statistik deskriptif, dalam kedua faktor yang dinilai tertinggi yaitu dapat berbelanja dengan nyaman dan komplit dan merasakan kelas yang sama secara psikologis. Lalu pada posisi berikutnya kesesuaian dengan gaya hidup, disusul dengan faktor dapat membeli dengan harga yang sesuai dan mau melakukan aktivitas di pusat belanja. Adapun faktor-faktor dapat berbelanja dengan nyaman dan komplit, harga yang sesuai dan mau melakukan aktivitas lebih lama di pusat belanja mendukung nilai fungsi transaksi dari pusat belanja. Sedangkan kedua faktor lainnya, merasakan kelas yang sama dan kesesuaian dengan gaya hidup meru- 
pakan nilai eksperensial dari sebuah pusat belanja. Keseimbangan ini dapat dinilai baik mengingat fungsi pusat belanja modern adalah untuk dapat menjadi media belanja sekaligus memberikan hiburan bagi pengunjung yang datang.

\section{PENUTUP}

Sebagai penutup, pada penelitian ini telah dapat disimpulkan bahwa pusat belanja atmosphere berpenaruh terhadap shopping value terhadap pengunjungnya dalam kasus penelitian ini, utamanya interior features. Adapun kedua faktor lainnya tetap dapat ditingkatkan untuk memberikan keunggulan bagi pusat belanja.

Dari analisis di atas dapat diajukan dua buah rekomendasi. Pertama, hal ini hendaknya menjadi perhatian dalam pengelolaannya dalam level manajerial (secara praktek), maupun dalam pengembangan teori (secara teoritis) untuk kondisi Indonesia yang memiliki prospek properti yang berkembang di masa yang akan datang. Di mana pengkondisian interior adalah yang utama untuk kasus-kasus serupa pada pusat belanja yang tertutup. Tidak menutup kemungkinan penelitian pada jenis pusat belanja yang berbeda untuk meninjau pengaruh faktor-faktor atmosfer pusat belanja terhadap shopping value.

Kedua, populasi dalam penelitian ini dibatas pada usia yang memiliki orientasi high achievement (18-35 tahun). Masih terbuka penelitian dengan segmen usia yang berbeda maupun dengan etnik yang berbeda sesuai dengan karakteristik masing-masing segmen yang dituju oleh pusat belanja.

\section{DAFTAR PUSTAKA}

Areni, C.and D. Kim 1994. The Influence of In Store Lighting on Consumer Examination of Merchandise in a Wine Store. International Journal of Research in Marketing. 11.117-125.

Barr, V. and C. Broudy. 1997. Designing To Sell, A Complete Guide to Retail Design and Planning. New York. McGraw Hill.

Baker, J., Grewal. andM. Levy. 1992. An Experimental Approach to Make Retail Store Environmental Decision. Journal of Retailing. 68 (4). 445-60.
Burns, D. and L. Neisner. 2006. Customer Satisfaction in Retail Setting: The Contribution of Emotion. International Journal of Retail \& Distribution Management. 34 (1). 49-66.

Caru, A. and B.Cova. 2006. Consuming Experience. London. Routledge

Castaldo, S. and C. Mauri. 2008. Store Management. Milano. Franco Angeli.

Donovan, R.J. dan J. Rossiter. 1982. Store Atmosphere: An Environmental Psychology Approach.Journal of Retailing. 58. 34-57.

Fiore, A.M 2008. The Shopping Experience in Schifferstein, Hendrik. \& Paul, Hekkert. 2009. Product Experience. Oxford. Elsevier.

Fiore, A. And J. Kim. 2007. An Integrative Framework Capturing Experential and Utilitarian Shopping Experience. International Journal of Retail and Distribution Management. 35 (6). 421 42.

Fox, R. And R. Sethuraman. 2006. Retail Competition, in Kraft, M dan Mantrala, M. K. (Eds), Retailing in the $21^{\text {st }}$ Century: Current and Emerging Trends. Springer, Berlin. 239-54.

Gardner, M. 1985. Mood States And Consumer Behaviour: A Critical Review. Journal of Consumer Research. 12 (3). 281-300

Grewal, D. and Levy, M. 2007. Retailing Research: Past, Present and Future. Journal of Retailing. 83 (4). 447-64.

Hair, Jr, JF., W.C.Black., B.J. Babin., R.E. Anderson, and R.L. Tahtam. 2006. Data analysis Multivariate 6 th. Ed. New Jersey. Upper Saddle River. Pearson Education.

Ibrahim, I.S. 2007. Lifestyle Ecstasy, Kebudayaan Pop Dalam Masyarakat dan Komoditas Indonesia. Mizan. Yogyakarta.

Kaltcheva, V. dan B. Weitz. 2006. The Moderationg Influence of Motivational Orientation on the Relationship Between Shopping Environment Arousal and 
Behaviour, Journal of Marketing. Winter. 107-18.

Kent, T .2007. Creative Space: Design and The Retail Environment. International Journal of Retail \& Distribution Management. 35 (9). 734-45.

Kurniawan, S. 2012. Pusat belanja Jawaban Gaya Hidup Urban.The Marketeers Magazine, Agustus 2012. 57-59.

Kusumowidagdo, A. 2005.Analisis Pengaruh Persepsi Atas Variabel-Variabel Store Atmosfer Terhadap Store Choice Pada Pengunjung Fashion Retail di Supermal Pakuwon Indah Surabaya. Thesis Tak Diterbitkan. Program Magister Manajemen Universitas Airlangga. Surabaya.

Kusumowidagdo, A. 2009. Perbedaan Persepsi Secara Gender Atas Desain Toko Ritel Terhadap PerilakuBelanja. Penelitian Tak Diterbitkan. Universitas Ciputra: Surabaya.

Kusumowidagdo, Astrid. 2010.Desain Ritel. Gramedia Pustaka Utama.Jakarta.

Kusumowidagdo, A.,A. Sachari., dan P. Widodo. 2012a.Shoppers Perception on Physical Condition of Shopping Centre Atmosphere at Different Lifecycle. International Research Journal of Business Studies. 5 (2).1-8.

Kusumowidagdo, A, A. Sachari., dan P. Widodo. 2012b. The Impact of Atmospheric Stimuli of Stores on Human Behaviour, Procedia Social andBehavioural Science, 35, 564-571. Retrieved June, $15^{\text {th }}$, 2013, from www. science direct.com

Kusumowidagdo, A; A. Sachari., dan P. Widodo. 2012c. The Physical Construction of Sense of Place. A Case of Ciputra world Shopping Centre of Surabaya. Proceeding ofInternational Conference on Culture, Society, Technology and Urban Development in Nusantara, Universitas Panca Budi, Medan, 13-14 September 2012.

Kusumowidagdo, A; A. Sachari., dan P. Widodo. 2012d. Persepsi Pengunjung
Pada Desain Pusat Belanja, Sebuah Survey Eksploratif pada Pusat belanja Ciputra Dan Senayan City Jakarta. Proceeding of Seminar Nasional Desain Teknik dan Perencanaan, Universitas Pelita Harapan, Karawaci. 29 November 2012.

Kusumowidagdo, A; A. Sachari., P. Widodo. dan B. Sugiharto. 2012f.Preferensi Pengunjung Pada Simulasi Kota Mini Pada Ruang Publik Pusat Belanja Sebagai Produk Budaya Populer. Proceeding of Seminar Nasional Tranformasi Sosial dan Budaya. Dies Natalis Fisip ke 27, Universitas Jendral Soedirman, Purwokerto. 31 Oktober 2012.

Kusumowidagdo, A., A. Sachari., dan P. Widodo.2013a. Journal of Engeenering Technology. 2 (1). 1-10.

Kusumowidagdo, A., A. Sachari., dan P. Widodo. 2013b. Perkembangan Desain Ruang Publik Pada Interior Pusat Belanja. Proceeding Seminar Nasional Urban Accupunture, Fakultas Seni Rupa dan Desain, Universitas Kristen Maranatha Bandung 29 Oktober 2013.

Kramer, A. 2008. Urban Land Institute. Washington DC. Retail Development.

Kotler, P. 1973. Atmospheric as Marketing Tool. Journal of Marketing. 49 (Winter), 48-61.

Mehrabian, A. and J. Russel. 1978.An Approach to Environmental Psychology. Cambridge. MIT Press.

Miliman, R. 1986. The Influence of Restaurants Patrons. Journal of Consumer Research. September- December. 296307.

Papalia, D., Olds \& Feldman. 2009. Human Develompment Trans. Brian Marswensdy. Jakarta. Penerbit Salemba Humanika.

Pine dan Gilmore. 1998. Welcome To The Experience Economy. Harvard Business Review. Juni-Agustus. 97-105.

Pinto, M.B. and L. Leonidas. 1994. The Impact of Office Characteristics on 
Satisfaction with Medical Care: A "Before and After" Study. Health Marketing Quarterly. 12. 43-54.

Prahalad, C. K. and Ramaswany, V. 2004. The Future of Competition: Creating Unique Value with Customer. Strategy and Leadership. 32 (3). 4-9.

Relph, E. 1976. Place and Placelessness. London. Pion.

Sands, S., H. Oppewal. and M. Beveland. 2010. The Influence of In-Store Experential Events on Shopping Value Perception and Shopping Behaviour. International Journal of Retail \& Distribution Management. 42 (1). 11-20.

Schmidtt, B. 1999.Experential Marketing: How To Get To Customer Sense, Feel, Think, Act and Relate To Your Company and Brands. New York. Free Press.

Spena, Tiziana Russo., A. Carida., M. Colurcio., dan M. Melia.2012. Store
Experience and Co Creation: The Case of Temporary Shop. International Journal of Retail \& Distribution Management. 40 (1). 21-40.

Soeprajitno, Hendra. 2012. Keep Calm and Let's Go To the Pusat belanja: Tetap Tenang dan Marilah Kita ke Pusat belanja. The Marketeers Magazine. August 2012. 54-46.

Wee dan Tong. 2005. The 4RS of Asian Shopping Centre Management. Jakarta. PT Buana Ilmu Populer.

Williams. 2006. Design for Experience: A New Rationale. Journal of Design Education and Technology. 2 (2).9-19.

Turley, L.W. and R. Milliman. 2000. Atmospherics Effect on Shopping Behaviour: A Review Of The Experimental Evidence. Journal of Business Research. 49. 193-211.

Zumthor, P. 2006. Atmospheres. Switzerland. Birkhauser. 